\title{
Estimasi Selektivitas Gillnet Dasar Pada Penangkapan Ikan Lencam (Lenthrinus spp) di Perairan Obi Kabupaten Halmahera Selatan Propinsi Maluku Utara
}

\author{
Safrudi Ode Idris ${ }^{1}$, Umar Tangke ${ }^{2}$ dan Bernhard Katiandagho ${ }^{3}$ \\ ${ }^{1}$ Alumni Prodi THP Fakultas Pertanina, Universitas Muhammadiyah Maluku Utara. Ternate. Indonesia, \\ Email : safrudinodei@yahoo.com \\ 2 Staf Pengajar Fakultas Pertanian, Universitas Muhammadiyah Maluku Utara. Ternate. Indonesia, \\ Email : umbakhaka@gmail.com \\ 3 Akademi Kamasan Biak, Biak-indonesia, E-mail : bernhard220575@gmail.com \\ ${ }^{凶}$ Korespondensi : $\quad$ Umar Tangke, Universitas Muhammadiyah Maluku Utara, Ternate, Indonesia, \\ Email : umbakhaka@gmail.com
}

\begin{abstract}
ABSTRAK
Penelitian ini bertujuan untuk menentukan ukuran mata jaring yang tepat pada alat tangkap gillnet dasar pada penangkapan ikan lencam (Lethrinus spp) di perairan Pulau Obi Kabupaten Halmahera Selatan Propinsi Maluku Utara. Penelitian ini dilaksanakan mulai bulan Juli sampai bulan Agustus 2096 di perairan Pulau Obi Kabupaten Halmahera Selatan Propinsi Maluku Utara. Jenis gill net yang digunakan selama penelitian yaitu jaring insang dasar (bottom gillnet). Bagian dari alat tangkap ini terdiri dari jaring utama (webbing), pelampung (float), pemberat (sinker), tali ris atas dan tali ris bawah, dan tali slambar. Jaring utama (badan jaring) yang digunakan dalam penelitian terbaut dari bahan tasi (monofilamen) nomor 40, dengan panjang 80 meter/piece, lebar jaring 2,5 meter dengan ukuran mata jaring (mesh size) adalah 5,08 cm dan $6,35 \mathrm{~cm}$. Jumlah jaring yang digunakan dua unit alat gillnet dasar dengan ukuran mata jaring yang berbeda. Dengan melihat perikanan demersal yang cukup potensial khususnya ikan lencam (Lethrinus spp) dan dalam rangka menjaga kelestarian ikan lencam maka sebaiknya alat tangkap gill net yang digunakan mempunyai ukuran mata jaring yang besarnya $6,35 \mathrm{~cm}$, sehingga hasil tangkapan yang diperoleh maksimal tanpa menganggu kelestarian ikan lencam.
\end{abstract}

\section{Keyword: Selektivitas, gill net, lencam, Lenthrinus spp}

\section{PENDAHULUAN}

\subsection{Latar Belakang}

Maluku Utara merupakan wilayah kepulauan yang menyebar dengan luas daratan $\pm 77.990 \mathrm{~km}^{2}$ dan luas lautan $\pm 776.500 \mathrm{~km}^{2}$ (DKP Prop Maluku Utara, 2013). Luas lautan yang hampir $73 \%$ merupakan tempat hidup berbagai macam sumber daya perairan. Tercatat ada tiga wilayah pengelolaan perikanan dari 9 wilayah pengelolaan yang ada di Indonesia diantaranya laut Banda, laut Seram dan laut Maluku. Pulau Obi merupakan bagian dari Kabupaten Halmahera Selatan yang terletak dibagian selatan pulau Halmahera dan merupakan salah satu bagian dari Propinsi Maluku Utara. Kabupaten Halmahera Selatan memiliki potensi perikanan yang cukup besar. Tercatat produksi perikanan selama tahun 2013 mencapai 154.67 ton dengan rata-rata produksi pertahun mencapai 121.4 ton, dan produksi tertinggi pada tahun 2011 mencapai 186.56 ton (DKP HALSEL, 2014).

Besarnya potensi yang ada memungkinkan berkembangnya perikanan melalui pengoperasian berbagai jenis alat tangkap antara lain purse seine, Pole and line, gill net, bagan, hand line dan lain-lain. Salah satu alat tangkap yang sering digunakan oleh nelayan khususnya nelayan Obi adalah gillnet dasar. Perkembangan alat ini cukup pesat dan menempati urutan kedua setelah purse seine dan merupakan alat tangkap yang cukup efisien dan relatif murah bila dibandingkan dengan alat tangkap lainnya. Gillnet dasar merupakan alat tangkap yang bersifat pasif, alat ini dioperasikan untuk menangkap berbagai jenis ikan yang hidup pada perairan dasar (demersal) antara lain adalah ikan lencam dan berbagai spesies lainya. 
Ikan lencam tergolong ikan demersal yang bernilai ekonomis penting, hal ini disebabkan oleh banyaknya permintaan pasar dan masyarakat yang umumnya mengkonsumsi daging ikan lencam serta tingginya produksi hasil tangkapan ikan lencam yang rasanya lezat dan gurih serta kandungan gizi yang tinggi. Keberhasilan operasi penangkapan alat tangkap gillnet dasar sangat ditentukan oleh parameter desain alat seperti ukuran benang, bahan benang dan material, hanging ratio, kecepatan menarik, cara penangkapan serta ukuran mata jaring (Fridman, 1986).

Ukuran mata jaring memiliki peranan penting dalam selektivitas hasil tangkapan sehingga dapat dijadikan sebagai standar untuk menentukan ukuran ikan yang akan tertangkap, sehingga pada umumnya kelestarian sumberdaya ikan lencam sangat tergantung pada ukuran mata jaring. Berdasarkan pertimbangan selektivitas dan untuk mendapatkan hasil tangkapan yang berukuran besar dengan tetap menjaga kelestarian sumberdaya, maka hendaklah ukuran mata jaring disesuaikan besarnya dengan ukuran ikan yang menjadi tujuan penangkapan. Dengan demikian untuk mengetahui ukuran mata jaring mana yang lebih selektif untuk di operasikan maka perlu dilakukan penelitian tentang selektivitas alat tangkap gillnet dasar pada penangkapan ikan Lencam di perairan Pulau Obi Kabupaten Halmahera Selatan Propinsi Maluku Utara.

\subsection{Tujuan dan Manfaat Penelitian}

Penelitian ini bertujuan untuk menentukan ukuran mata jaring yang selektif pada alat tangkap gillnet dasar pada penangkapan ikan Lencam (Lethrinus spp) di perairan Pulau Obi Kabupaten Halmahera Selatan Propinsi Maluku Utara.

Hasil penelitian ini diharapkan dapat menjadi bahan informasi untuk nelayan dan bagi pengembangan perikanan khususnya dalam menentukan alat tangkap yang selektif (gillnet dasar), sehingga diperoleh hasil yang optimal dengan tetap memperhatikan potensi sumberdaya perikanan.

\section{METODE PENELITIAN}

\subsection{Waktu dan Tempat}

Penelitian ini dilaksanakan mulai bulan Juli sampai bulan Agustus 2019 di perairan Pulau Obi Kabupaten Halmahera Selatan Propinsi Maluku Utara.

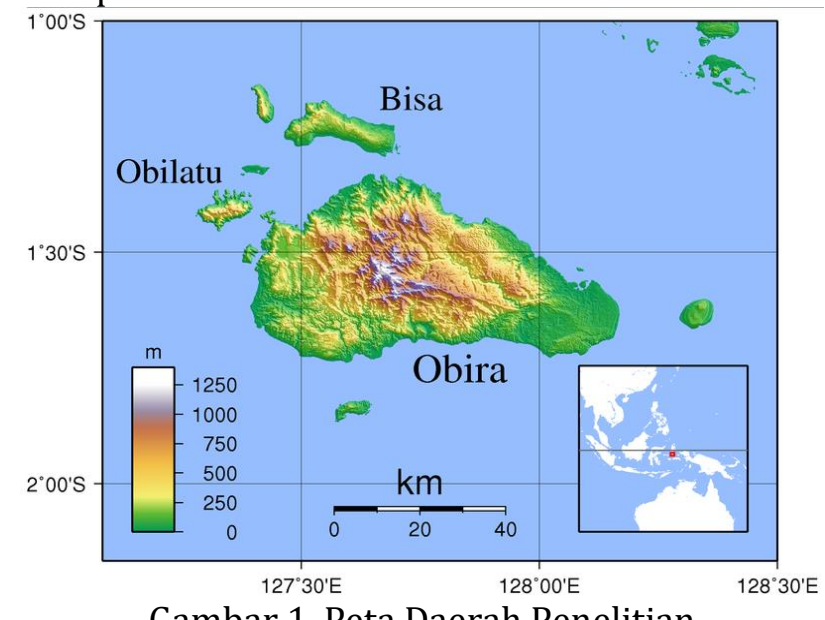

\subsection{Bahan dan Alat}

Gambar 1. Peta Daerah Penelitian

Bahan yang digunakan dalam penelitian ini adalah ikan lencam (Lethrinus spp) yang diperoleh dari hasil tangkapan nelayan dengan menggunakan alat tangkap gillnet dasar yang mempunyai mesh size berbeda. Sedangkan alat yang digunakan dalam penelitian ini adalah 2 unit gillnet dasar dengan panjang masing-masing 70 meter dan lebar 2,5 meter dengan ukuran mesh size yang berbeda 5,08 cm dan $6,35 \mathrm{~cm}$, mistar pengukur, timbangan untuk mengukur berat ikan, alat tulis menulis.

\subsection{Metode penelitian}

Metode pengumpulan data yang digunakan dalam penelitian ini adalah dengan metode survei (pengamatan langsung di lapangan) dengan cara mengikuti langsung operasi penangkapan. Pengoperasian alat dilakukan hampir setiap hari dengan sistem selang-seling. Pemberangkatan dari fishing base ke lokasi penangkapan pada pukul 10.00 WIT dan tiba di fishing ground pada pukul 11.30 WIT. Pemasangan dan penarikan jaring dilakukan 1-2 kali dalam satu hari (per trip) sampai 
menjelang, sore hari, dengan lama perendaman alat untuk satu kali penurunan jaring berkisar 1-2 jam. Setelah masa perendaman jaring selesai, maka dilakukan hauling dengan pengangkatan pelampung tanda pertama, kemudian dikuti dengan penarikan badan jarring secara keseluruhan sampai pada penganngkatan pelampung terakhir/ pelampung tanda kedua. Pada saat pengangkatan jaring juga dilakukan pengumpulan hasil tangkapan. Setelah keseluruhan jaring dan hasil tangkapan diangkat kemudian kapal meninggalkan fishing ground menuju fishing base.

\subsection{Analisis Data}

Parameter-parameter yang dihitung untuk penentuan selektivitas gillnet dasar adalah panjang optimum (Lm), standar deviasi (s) dan peluang tertangkap (P), dengan menggunakan model Holt (1963 dalam Sparre 1989).

\subsubsection{Panjang optimum (Lm)}

a. Data hasil tangkapan diukur kemudian di input untuk analisis menurut kelompok panjang untuk masing-masing mata jaring, dengan menghitung nilai Y untuk masing-masing kelompok panjang dengan rumus :

$$
Y=\ln (\mathrm{Cb} / \mathrm{Ca})
$$

Dimana:

$$
\begin{aligned}
& \mathrm{Y}=\text { Logaritma natural hasil tangkapan mata jaring } \mathrm{Cma} \text { dan } \mathrm{Cmb} \\
& \mathrm{Ca}=\text { Hasil tangkapan pada mata jaring a. } \\
& \mathrm{Cb}=\text { Hasil tangkapan pada mata jaring } \mathrm{b} .
\end{aligned}
$$

b. Langkah kedua adalah meregresikan logaritma natural hasil tangkapan (Y) dengan nilai tengah interval panjang (X). Sehinga persamaan akan membentuk $\ln (\mathrm{Cb} / \mathrm{Ca})=a+b \cdot L$.

Dimana: $\quad \mathrm{Ca} \quad=$ Hasil tangkapan pada mata jaring a

$\mathrm{Cb}=$ Hasil tangkapan pada mata jaring $\mathrm{b}$.

$\mathrm{A}=$ Konstanta (titik potong) digaris regresi pada sumbu Y/intercept.

$\mathrm{B}=$ Koefisien regresi / kemiringan atau slope daripada garis regresi.

$\mathrm{L} \quad=$ Variabel bebas / nilai tengah kelas panjang.

c. Selanjutnya persamaan yang telah analog dengan persamaan regresi sederhana ini kemudian digunakan untuk menghitung panjang optimum ikan yang tertangkap pada masing-masing jaring yaitu :

\section{Dimana :}

$$
\begin{aligned}
& L m a=-2(a \cdot m a) / b(m a+m b) \\
& L m b=-2(a \cdot m b) / b(m a+m b)
\end{aligned}
$$

$$
\begin{aligned}
\mathrm{Lma}= & \text { Panjang optimum ikan yang tertangkap pada mata jaring yang ukurannya kecil } \\
\mathrm{Lmb}= & \text { Panjang jaring } \mathrm{a} \text { ) } \\
& \text { besar (mata jaring b). } \\
\mathrm{a}= & \text { Konstanta (titik potong) digaris regresi pada sumbu Y / intercept. } \\
\mathrm{b} & =\text { Koefisien regresi / kemiringan atau slope daripada garis regresi. } \\
\mathrm{ma} & =\text { Lebar mata jaring ukuran kecil } \\
\mathrm{mb} & =\text { Lebar mata jaring ukuran besar }
\end{aligned}
$$

\subsubsection{Standar Deviasi (s)}

Standar deviasi atau simpangan baku (s) untuk kedua mata jaring yang berbeda ukurannya diperoleh dari :

$$
\left.s=\left(2 . a(m a-m b) / b^{2}(m a+m b)\right)\right)^{1 / 2}
$$

Dimana :
$\mathrm{s}=$ Standar deviasi / simpangan baku
$\mathrm{a}=$ Konstanta (titik potong) digaris regresi pada sumbu Y / intercept
$\mathrm{b}=$ Koefisien regresi / kemiringan atau slope daripada garis regresi.
ma = Lebar mata jaring ukuran kecil
$\mathrm{mb}=$ Lebar mata jaring ukuran besar

\subsubsection{Peluang Tertangkap (P)}

Setelah mendapatkan nilai panjang optimum ikan yang tertangkap pada mata jaring a (Lma) dan mata jaring b (Lmb) serta standar deviasi (s) maka peluang tertangkap (P) untuk panjang tertentu (L) pada mata jaring $(\mathrm{m})$ adalah : 
$P m a=\exp (-L-L m a)^{2} / 2 s^{2}$

$P m b=\exp (-L-L m b)^{2} / 2 s^{2}$

Dimana :

Pma = Peluang ikan yang tertangkap pada mata jaring ukuran kecil (mata jaring a).

Pmb = Peluang ikan yang tertangkap pada mata jaring ukuran besar (mata jaring b).

$\mathrm{L} \quad=$ Variabel bebas / nilai tengah kelas panjang.

Lma = Panjang optimum ikan yang tertangkap pada mata jarring yang ukurannya kecil (mata jaring a).

$\mathrm{Lmb}=$ Panjang optimum ikan yang tertangkap pada mata jarring yang ukurannya besar (mata jaring b).

$\mathrm{s} \quad=$ Standar deviasi / simpangan baku.

Disamping itu penentuan selektivitas gillnet dasar dapat juga dianalisis dengan mengetahui nilai shortening. Untuk mengetahui nilai shortening Ayodhya (1981) menggunakan rumus sebagai berikut :

$S=((L-I) / L) \times 100 \%$

Dimana: $\quad \mathrm{S}=$ Shortening $(\%)$

$\mathrm{I}=$ Panjang tali ris $(\mathrm{m})$

$\mathrm{L}=$ Panjang jaring $(\mathrm{m})$

Penentuan hubungan panjang ikan dengan tinggi badan yang menentukan mesh size menggunakan rumus umum persamaan linear sebagai berikut :

$Y=a+b X$

Dimana :

$\mathrm{Y}=$ Variabel tak bebas, tinggi badan ikan $(\mathrm{cm})$

$\mathrm{X}=$ Variabel bebas, nilai tengah kelas panjang total $(\mathrm{cm})$

$\mathrm{a}=$ Konstanta (titik potong) digaris regresi pada sumbu Y intercept.

$\mathrm{b}=$ Koefisien regresi / kemiringan atau slope daripada garis regresi.

\section{HASIL DAN PEMBAHASAN}

\subsection{Deskripsi Alat Tangkap}

Walau terdapat perbedaan pokok pada tiap-tiap jenis gillnet sesuai dengan klasifikasinya, namun secara umum giilnet mempunyai bentuk yang umum yang terdapat pada tiap-tiap jenis sehingga tiap jenis gillnet tersebut mempunyai persamaan bentuk pokok. Defenisi bentuk gillnet secara umum adalah empat persegi panjang, dimana bentuk alat ini merupakan bentuk alat penangkapan ikan yang paling sederhana.

Jenis gillnet yang digunakan selama penelitian yaitu jaring insang dasar (bottom gillnet). Bagian-bagian dari alat tangkap ini terdiri dari jaring utama (webbing), pelampung (float), pemberat (sinker), tali ris atas dan tali ris bawah, dan tali slambar. Jaring utama (badan jaring) yang digunakan dalam penelitian terbaut dari bahan tasi (monofilamen) nomor 40, dengan panjang 80 meter/ piece, lebar jaring 2,5 meter dengan ukuran mata jaring (mesh size) adalah 5,08 cm dan 6,35 cm. Jumlah jaring yang digunakan untuk satu unit alat gillnet dasar dengan ukuran mata jaring yang berbeda yaitu 2 piece, sedangkan jumlah unit gillnet dasar yang digunakan sebanyak dua unit dengan ukuran mata jaring yang berbeda.

Tali ris pada aat tangkap jaring insang dasar terdiri dari tali ris atas dan tali ris bawah yang terbuat dari bahan polyethylene dengan diameter $5 \mathrm{~mm}$ dan panjang tali ris 35 meter/piece. Panjang tali ris untuk 2 piece jaring secara keseleruhan yaitu 70 meter dengan jumlah keseluruhan panjang badan jaring 140 meter.

Tali ris atas berfungsi untuk melekatkan jaring dan mengikat tali pelampung, sedangkan tali ris bawah digunakan untuk melekatkan jaring sekaligus berfungsi untuk mengikat pemberat. Tali slambar terdiri dari tali slambar depan dan tali slambar belakang dengan ukuran panjang 8 meter. Fungsi dari tali slambar adalah untuk mengikatkan pelampung tanda.

Pada jaring insang dasar digunakan dua macam pelampung yaitu pelampung jaring dan pelampung tanda. Pelampung jaring terbuat dari sendal bekas berbentuk oval dengan diameter $4 \mathrm{~cm}$, dengan jarak antara pelampung $33 \mathrm{~cm}$. Pelampung tanda tebuat dari bahan polyvinyl chloride dengan diameter $30 \mathrm{~cm}$, berbentuk bola. Fungsi dari pelampung tanda yaitu sebagai tanda bahwa jaring sedang dioperasikan di suatu daerah penangkapan. Pelampung jaring pada gillnet dasar berfungsi untuk mengangkat tali ris atas agar jaring dapat terentang sempurna dalam perairan. 
Pemberat yang digunakan terbuat dari lempengan timah sebanyak 235 buah, dengan jarak antara pemberat $30 \mathrm{~cm}$, total berat keseluruhan pemberat 4,89 kg, selain itu digunakan pemberat tambahan dari batu sebanyak 6-10 buah, berat batu disesuaikan dengan keadaan jaring.

\subsection{Kapal/Perahu Penangkapan}

Pada umumnya kapal/perahu yang digunakan untuk mengoperasikan alat tangkap jaring insang dasar di perairan Halmahera selatan (Obi) terbuat dari material kayu dengan bentuk dan ukuran yang hampir sama. Ukuran utama kapal/perahu yang digunakan selama penelitian yaitu 4,8 meter, lebar perahu $60 \mathrm{~cm}(0,6$ meter $)$ dan tinggi kapal $52 \mathrm{~cm}(0,52$ meter $)$ dengan kapasitas muat 0,7 ton. Material perahu terbuat dari kayu kenari, untuk menggerakkan kapal tidak digunakan mesin, tetapi dengan cara mendayung karena daerah penangkapan yang dituju tidak terlalu jauh dari fishing base. Jumlah tenaga kerja dalam melaksanakan operasi penangkapan terdiri dari 2 - 3 orang, dengan masing-masing tenaga kerja mempunyai tugas yang berbeda pada saat operasi penangkapan dilakukan.

\subsection{Metode Penangkapan}

Sebagaimana operasi penangkapan lainnya tahap pertama yang harus di perhatikan dalam mengoperasikan alat tangkap jaring insang dasar adalah persiapan operasi penangkapan yang meliputi persiapan alat tangkap, kapal dan lain-lainnya. Kapal meninggalkan fishing base sekitar pukul 10.00 WIT untuk penangkapan pertama dan sekitar pukul 11.30 WIT dilakukan penangkapan kedua untuk satu hari penangkapan, sedangkan waktu yang dibutuhkan untuk ke daerah penangkapan sekitar 20 - 35 menit. Setelah tiba di fishing ground proses setting siap dilaksanakan, setting berlangsung sekitar pukul 11.30 WIT untuk trip pertama sedangkan trip kedua berlangsung sekitar pukul 14.00 WIT. Setting dimulai dengan penurunan pelampung tanda dan pemeberat batu secara bersamaan kemudian di ikuti dengan penurunan badan jaring, pelampung dan pemberat secara bersamaan sampai keseluruhan alat turun dan terendam dengan sempurna. Setting dilakukan di daerah yang masih ada pengaruh pasang surut dengan kedalaman 3 - 10 meter.

Setelah setting selesai kemudian perendaman alat selama kurang lebih 1 - 2 jam, apabila keadaan cuaca yang tidak baik, maka setting tidak dilaksanakan. Setelah masa perendaman jaring selesai, kemudian dilakukan hauling sekitar pukul 12.30 WIT untuk hauling pertama, sedangkan untuk hauling kedua sekitar pukul 16.00 WIT. Pengangkatan jaring dilakukan mulai dari pengangkatan pelampung tanda sampai dengan pengangkatan keseluruhan badan jaring. Jaring yang sudah diangkat kemudian disusun kembali sedemikian sehingga mempermuda dalam operasi berikutnya.

\subsection{Daerah dan Musim Penangkapan}

Penentuan daerah penangkapan ikan merupakan salah satu faktor utama dalam keberhasilan operasi penangkapan. Pengetahuan tentang daerah penangkapan sangat penting dalam hubungannya dengan pembuatan suatu alat tangkap. Daerah atau lokasi penagkapan yang dilakukan merupakan suatu daerah yang masih terpengaruhi oleh pasang surut, dimana daerah penangkapan tersebut merupakan daerah yang subur dan terdapat berbagai jenis ikan yang mendiami derah tersebut.

Menuruit Ayodhyoa (1974 dalam Nirmalawati,1996) mengemukakan bahwa pengoperasian jaring insang baik dengan cara melingkari, menghadang dan mengejuti diperlukan pengetahuan tentang keadaan pasang surut serta tinggi jaring diusahakan sesuai dengan tujuan yang dimaksud. Ciri-ciri dari daerah penangkapan yaitu daerah yang ditumbuhi pohon bakau yang berdasar pasir campur lumpur serta daerah ini merupakan daerah yang subur karena merupakan daerah tempat tersedianya makanan serta tempat yang aman untuk ikan-ikan yang sedang memijah.

Lokasi atau daerah operasi penangkapan jaring insang dasar selama penelitian diperairan pulau Obi berada sekitar 100 - 400 meter dari fishing base dan daerah tersebut masih terpengaruh oleh pasang surut, serta berdekatan kurang lebih 100 meter dari hutan mangrove, dengan dasar perairan berpasir dan berkarang. Penangkapan ikan dengan alat tangkap gillnet dasar diperairan Pulau Obi berlangsung sepenjang musim. 


\subsection{Jumlah dan Komposisi Hasil Tangkapan}

Berdasarkan hasil identifikasi ikan yang tertangkap selama penelitian berlangsung didapatkan tiga jenis ikan lencam (Lethrinus spp) sebagai berikut: Lethrinus lentjan, Lethrinus ornatus dan Lethrinus obsoletus. Jumlah ikan lencam yang terukur selama penelitan sebanyak 500 ekor dengan kisaran panjang total $16-27,5 \mathrm{~cm}$. Berdasarkan hasil analisis distribusi frekuensi (Tabel. 1) menunjukan bahwa hasil tangkapan untuk kedua mata jaring antara lain 5,08 cm dan $6,35 \mathrm{~cm}$ terdiri dari 12 interval kelas. Jumlah hasil tangkapan yang paling sedikit terdapat pada interval kelas 16 - 17 $\mathrm{cm}$ dengan jumlah ikan lencam sebanyak 7 ekor, sedangkan jumlah ikan lencam yang paling banyak tertangkap pada interval kelas 21 - $22 \mathrm{~cm}$, dengan jumlah ikan sebanyak 82 ekor.

Tabel 1. Jumlah Hasil Tangkapan dan Panjang Ikan Untuk Ukuran Dua Mata Jaring Insang Dasar Yang Berbeda Untuk Estimasi Seleksi Ikan Lencam (Lethrinus spp) di Perairan Pulau Obi.

\begin{tabular}{|c|c|c|c|c|c|}
\hline \multirow[t]{2}{*}{ Interval Kelas } & \multirow[t]{2}{*}{$\begin{array}{c}\text { Nilai } \\
\text { Tengah } \\
\text { Kelas (L) } \\
\text { (X) }\end{array}$} & \multicolumn{2}{|c|}{$\begin{array}{c}\text { Jumlah Hasil } \\
\text { Tangkapan per } \\
\text { Ukuran mata Jaring } \\
\text { (cm) }\end{array}$} & \multirow[t]{2}{*}{$\begin{array}{c}\mathrm{Ln} \\
\mathrm{Cb} / \mathrm{Ca}\end{array}$} & \multirow[t]{2}{*}{ Keterangan } \\
\hline & & 5,08 & 6,35 & & \\
\hline $19-20$ & 19,5 & 47 & 9 & $-1,653$ & \multirow{5}{*}{$\begin{array}{l}\text { Dapat diestimasi karena } \\
\text { membentuk garis linier }\end{array}$} \\
\hline $20-21$ & 20,5 & 48 & 19 & $-0,968$ & \\
\hline $21-22$ & 21,5 & 46 & 36 & $-0,245$ & \\
\hline $22-23$ & 22,5 & 36 & 42 & 0,154 & \\
\hline $23-24$ & 23,5 & 20 & 40 & 0.693 & \\
\hline
\end{tabular}

Berdasarkan hasil perhitungan dan regresi sederhana ikan lencam (Lethrinus spp) maka diperoleh nilai $\mathrm{a}=-12,4726$ dan nilai $\mathrm{b}=0,5603$ sehingga persamaan regresi liniernya adalah $\mathrm{Y}=-$ $12,4726+0,5603 \mathrm{X}$ dengan standar deviasinya 2,971. Dari hasil perhitungan regresi linier maka dapat dihitung nilai panjang optimum ikan untuk kedua mata jaring yang berbeda yaitu untuk ukuran mata jaring 5,08 cm (Lma) panjang optimumnya 19,8 cm dan untuk ukuran mata jaring 6,35 $\mathrm{cm}$ (Lmb) panjang optimumnya $24,7 \mathrm{~cm}$.

Tabel 2, terlihat jumlah hasil tangkapan untuk kedua ukuran mata jaring yang paling banyak tertangkap adalah ikan Lencam yang berukuran 21 - $22 \mathrm{~cm}$ dengan presentasi 16,4 \%, sedangkan yang paling sedikit tertangkap adalah ikan Lencam yang berukuran 16-17 $\mathrm{cm}$ dengan presentasi 1,4 \%. Presentasi hasil tangkapan dapat dilihat pada Tabel 2.

Tabel 2. Presentasi Hasil Tangkapan Untuk Kedua Mata jaring Yang Berbeda Selama Penelitian Pada Penangkapan Ikan Lencam (Lethrinus spp) di Perairan Pulau Obi Kab Halmahera Selatan.

\begin{tabular}{cccc}
\hline \multirow{2}{*}{ INTERVAL KELAS } & \multicolumn{2}{c}{ Jumlah Hasil Tangkapan per Ukuran Mata } & \multirow{2}{*}{ Presentase (\%) } \\
\cline { 2 - 3 } & $\mathbf{5 , 0 8}$ & $\mathbf{6 , 3 5}$ & \\
\cline { 2 - 3 } $16-17$ & 7 & - & 1,4 \\
$17-18$ & 10 & - & 2 \\
$18-19$ & 14 & 4 & 3,6 \\
$19-20$ & 47 & 9 & 11,2 \\
$20-21$ & 48 & 19 & 13,8 \\
$21-22$ & 46 & 36 & 16,4 \\
$22-23$ & 36 & 42 & 15,6 \\
$23-24$ & 20 & 40 & 12 \\
$24-25$ & 15 & 55 & 12,8 \\
$25-26$ & - & 37 & 7,4 \\
$26-27$ & - & 16 & 2 \\
$27-28$ & - & 9 & 1,8 \\
\hline T O T A L & & & $\mathbf{1 0 0}$ \\
\hline
\end{tabular}

\subsection{Peluang Tertangkap}

Untuk menganalisis atau mengestimasikan peluang tertangkap ikan lencam maka sebelumnya didapatkan nilai panjang optimum ikan yang tertangkap pada ukuran mata jaring yang berbeda (Tabel 3 ), terlihat pada masing-masing ukuran mata jaring yang berbeda baik 5,08 cm (Pma) maupun 6,35 cm 
(Pmb) mempunyai peluang tertangkap yang hampir sama. Ukuran mata jaring 5,08 cm (Pma) yang paling banyak tertangkap pada interval kelas $19-20 \mathrm{~cm}$ dengan nilai 0,995 dengan nilai peluang tertangkap 99,5\%. Sedangkan untuk ukuran mata jaring 6,35 $\mathrm{cm}(\mathrm{Pmb})$ paling banyak tertangkap pada interval kelas 24-25 cm dengan nilai 0,998 dimana peluang tertangkap ikan untuk ukuran mata jaring $6.35 \mathrm{~cm}$ mencapai 99,8\%.

Hasil perhitungan yang ada menujukan bahwa kedua ukuran mata jaring mempunyai tingkat selektivitas yang berbeda pada penangkapan ikan lencam (Lethrinus spp).

Tabel 3. Estimasi Peluang Tertangkap Ikan Lencam (Lethrinus Spp) Untuk Kedua Ukuran Mata Jaring Yang Berbeda Di Perairan Pulau Obi.

\begin{tabular}{cccc}
\hline \multirow{2}{*}{ Interval Kelas } & \multirow{2}{*}{ Nilai Tengah Kelas } & \multicolumn{2}{c}{ Peluang Tertangkap } \\
\cline { 3 - 4 } & 19,5 & Pma & Pmb \\
\hline $19-20$ & 20,5 & 0,995 & 0,216 \\
$20-21$ & 21,5 & 0,973 & 0,368 \\
$21-22$ & 22,5 & 0,849 & 0,560 \\
$22-23$ & 23,5 & 0,662 & 0,760 \\
$23-24$ & 24,5 & 0,461 & 0,922 \\
$24-25$ & & 0,286 & 0,998 \\
\hline
\end{tabular}

Sumber: Diolah dari data Primer

Selain perhitungan terhadap peluang tertangkap, analisis lebih lanjut ditunjang dengan hasil perhitungan shortening untuk kedua ukuran mata jaring yang berbeda. Ketegangan rentangan tubuh jaring pada gillnet perlu diperhatikan karena sangat berpengaruh terhadap jumlah hasil tangkapan yang diperoleh, untuk itu perhitungan tentang ketegangan tubuh jaring (shortening) sangat diperlukan dalam pembuatan alat tangkap gillnet. Hasil perhitungan diperoleh panjang badan jaring untuk kedua unit alat tangkap yaitu 160 meter dan panjang tali ris 70 meter maka, nilai shortening untuk kedua unit alat tersebut adalah 56,3 \%. Menurut Ayodhyoa (1981), shortening yang baik agar ikan tertangkap secara terjerat bergerak antara 30-40\%. Hal ini jika dibandingkan dengan shortening yang diperoleh maka ada perbedaan nilai shortening, sehingga nilai shortening yang diperoleh menunjukan bahwa ikan tertangkap tidak secara terjerat. Nilai ini menunjukan bahwa nilai shortening yang diperoleh sebesar 56,3 \% merupakan nilai shortening dimana ikan yang tertangkap bisa secara gilled (terjerat) maupun engtangled (terbelit). Namun selama mengikuti operasi penangkapan didapatkan ikan yang tertangkap selama penelitian dominan secara gilled (terjerat).

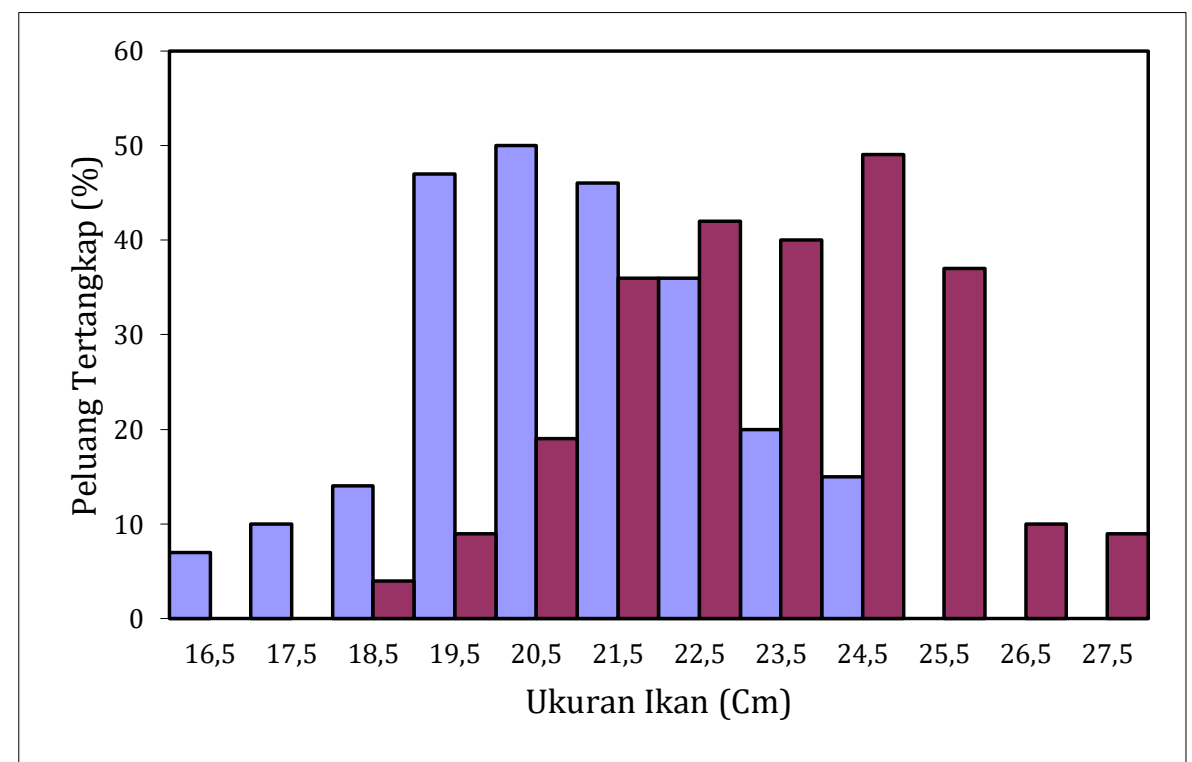

Gambar 2. Kurva Seleksi Gillnet Dasar Dalam Penangkapan Ikan Lencam (Lethrinus spp) di Perairan Pulau Obi Kab. Halmahera Selatan.

Dari hasil analisis seleksi (Gambar 2) menunjukan bahwa peluang tertangkap ikan lencam untuk kedua ukuran mata jarng hampir sama, dimana kurva seleksi bersifat simetris Panjang ikan 
lencam (Lethrinus spp) yang tertangkap selama penelitian berkisar antara $16-27,5 \mathrm{~cm}$. Sedangkan dari pemeriksaan tingkat kematangan gonad (TKG) didapatkan pada ukuran $180 \mathrm{~mm}$ ikan lencam sudah mencapai tingkat kematangan gonad ke-3 (TKG-III). Hal ini sejalan dengan yang dikemukakan oleh Naba (1992) dalam Nirmalawati (1996), bahwa ikan lencam pertama kali matang gonad di atas ukuran panjang $180 \mathrm{~mm}$ dengan berat 153 gr untuk ikan betina, sedangkan jantan matang gonad pada panjang $227 \mathrm{~mm}$ dengan berat di atas 153 gr. Lebih lanjut dikatakan bahwa kelompok umur ikan Lencam dengan rata-rata panjang 12-55 cm berkisar antara 1-6 tahun adalah ikan yang sudah pernah melakukan pemijahan. Berdasarkan ukuran panjang ikan yang telah matang gonad atau siap memijah, maka diduga ikan Lencam yang tertangkap untuk kedua ukuran mata jaring di perairan Pulau Obi sudah pernah melakukan pemijahan.

Alat tangkap gillnet dikatakan berkelanjutan apabila ikan yang menjadi tujuan penangkapan adalah ikan yang diduga pernah memijah atau ikan dengan ukuran tertentu yang sesuai dengan ukuran mata jaring (mesh size). Untuk menentukan ukuran ikan tertentu yang harus tertangkap dalam rangka menjaga kelestarian maka ukuran mata jaring merupakan salah satu faktor yang sangat menentukan, dimana semakin besar ukuran mata jaring yang digunakan semakin baik peluang untuk ikan yang berukuran besar/pernah memijah menjadi besar. Sebaliknya ukuran ikan yang kecil atau belum pernah memijah peluang tertangkapnya menjadi kecil.

Dari ukuran panjang total ikan Lencam (Lethrinus spp) yang tertangkap di perairan Pulau Obi antara 16-27,5 cm maka diduga bahwa ikan Lencam yang tertangkap untuk kedua ukuran mata jaring merupakan ikan yang berukuran besar dimana hal ini sejalan dengan yang dikemukakan oleh Dirjen Perikanan (1979), bahwa panjang ikan Lencam yang umumnya tertangkap berkisar antara 25-35 cm. Berdasarkan ukuran yang tertangkap maka hal ini menunjukan bahwa usaha penangkapan yang dilakukan masih sangat rendah, karena ikan Lencam yang tertangkap belum mencapai ukuran ratarata $35 \mathrm{~cm}$ atau lebih.

\subsection{Hubungan Panjang dan Tinggi Badan Ikan}

Spesies ikan yang menjadi tujuan penangkapan merupakan salah satu faktor penentu untuk merancang suatu unit alat tangkap,baik panjang jaring, lebar dan ukuran mesh size. Faktor penentu tersebut adalah ukuran panjang ikan, tinggi badan ikan. Pada alat tangkap gillnet, ukuran panjang dan tinggi badan ikan yang akan ditangkap merupakan salah satu factor utama dalam menentukan besar kecilnya ukuran mata jaring. Dalam rangka mempertahankan dan melestarikan suatu spesies ikan maka ikan yang di tangkap haruslah yang berukuran besar/pernah memijah, untuk itu mata jaring yang digunakan dalam penangkapan ikan harus sesuai dengan ukuran ikan yang menjadi tujuan penangkapan.

Berdasarkan hasil perhitungan analisis hubungan panjang dan tinggi badan ikan yang diperoleh menunjukan bahwa ada hubungan antara panjang ikan dengan tinggi badan ikan. Adapun hubungan panjang ikan dan tinggi badan ikan pada penangkapan ikan lencam (Lethrinus spp) untuk ketiga spesies yang tertangkap selama penelitian diperairan pulau Obi antara lain :

\subsubsection{Ikan Lencam Matahari (Lethrinus lentjam)}

Hasil perhitungan dan analisis hubungan panjang dan tinggi badan ikan dengan di dapatkan nilai $\mathrm{a}=-1,521$ dan nilai $\mathrm{b}=0,382$ dengan korelasi 0,994 . maka persamaan regresi liniernya adalah $\mathrm{Y}=-1,521+0,382 \mathrm{X}$. Hasil ini menunjukan hubungan positif, dimana dapat dikatakan bahwa untuk setiap X (panjang ikan) bertambah sebesar $1 \mathrm{~cm}$, maka tinggi badan ikan (Y) akan bertambah sebesar $0,235 \mathrm{~cm}$. Nilai korelasi yang diperleh menunjukan nilai positif yang kuat, artinya hubungan antara panjang dan tinggi badan ikan bersifat positif. Hal ini jika bertambahnya ukuran panjang ikan maka tinggi badan ikan akan bertambah.

\subsubsection{Ikan Sikuda (Lethrinus Ornathus)}

Hasil analisis hubungan panjang dan tinggi badan ikan, didapatkan nilai $a=0,21$ dan nilai $b=$ 0,30 dengan korelasi ( $\mathrm{r}$ ) adalah 0,953 . Persamaan linear yang terbentuk adalah $\mathrm{y}=0,21+0,30 \mathrm{X}$, hasil analisis ini menunjukan bahwa ada hubungan antara panjang ikan dengan tinggi badan ikan, dimana penambahan ukuran panjang ikan sebesar $1 \mathrm{~cm}$, maka tinggi badan ikan akan bertambah sebesar 0,30 $\mathrm{cm}$. Korelasi yang terbentuk bersifat positif, dengan demikian setiap bertambahnya ukuran panjang maka tinggi badan ikanpun akan bertambah. 


\subsubsection{Ikan Lencam Merah (Lethrinus obsoletus)}

Hasil analisis yang diperoleh, nilai $\mathrm{a}=-0,427$ dan $\mathrm{b}=0,342$ dengan nilai korelasinya adalah 0,993 , sehingga persamaan reresi linear yang terbentuk adalah $y=-0,427+0,342 \mathrm{X}$. Nilai ini masih menunjukan hubungan positif kuat, dimana setiap penambahan panjang ikan sebesar $1 \mathrm{~cm}$, maka tinggi badan akan bertambah sebesar $0,342 \mathrm{~cm}$, sedangkan jenis korelasinya adalah korelasi positif yang kuat dengan demikian setiap penambahan ukuran panjang ikan makin tinggi badan ikapun akan bertambah.

\section{PENUTUP}

Berdasarkan hasil penelitian yang dilakukan di perairan Pulau Obi Kabupatan Halmahera Selatan, maka penulis dapat mengambil beberapa kesimpulan bahwa hasil identifikasi ikan selama penelitian didapatkan tiga jenis ikan lencam (Lethrinus spp) antara lain : Lethrinus lentjan, Lethrinus cornatus dan Lethrinus obselotus, dengan panjang total ikan yang tertangkap berkisar antara $16-27,5 \mathrm{~cm}$, dengan peluang tertangkap terbanyak untuk kedua ukuran mata jaring hampir sama, dari total penangkapan sebanyak 500 ekor. Peluang tertangkap terbanyak untuk ukuran mata jaring $5,08 \mathrm{~cm}$ berada pada interval kelas 19-20 cm dengan nilai 0,995 atau 99,5\%. Sedangkan peluang tertangkap terbanyak untuk ukuran mata jaring $6,35 \mathrm{~cm}$ berada pada interval kelas $24-25 \mathrm{~cm}$ dengan nilai 0,998 atau 99,8 \%. Dari hasil perhitungan regresi linier didapatkan hubungan panjang ikan dan berat ikan lencam (Lethrinus spp) bersifat positif dimana setiap penambahan panjang ikan maka badan ikan juga akan ikut bertambah. selain itu ukuran mata jaring untuk kedua alat mempunyai selektifitas yang berbeda. ukuran mata jaring $6,35 \mathrm{~cm}$ lebih selektif bila dibandingkan dengan ukuran mata jaring 5,08 cm, dimana peluang tertangkap untuk ikan yang sudah pernah melakukan pemijahan semakin besar untuk ukuran mata jarin $6,35 \mathrm{~cm}$ dan untuk peluang tertangkap ikan yang belum pernah memijah semakin kecil. dan berdasarkan ukuran spesies yang tertangkap diduga sebagian besar ikan yang tertangkap adalah ikan yang pernah melakukan pemijahan, dimana ukuran ikan yang tertangkap relatif besar berkisar antara $24-27,5 \mathrm{~cm}$ dari total panjang maksimum ikan Lencam antara 25-35 cm. Untuk menjaga kelestarian sumberdaya alam khusunya potensi ikan Lencam maka ukuran mata jaring yang baik digunakan adalah ukuran mata jaring yang besar untuk mencegah tertangkapnya ikan yang berukuran kecil.

Dengan melihat perikanan demersal yang cukup potensial khususnya ikan Lencam (Lethrinus spp) dan dalam rangka menjaga kelestarian ikan Lencam maka sebaiknya alat tangkap gillnet yang digunakan mempunyai ukuran mata jaring yang besarnya $6,35 \mathrm{~cm}$, sehingga hasil tangkapan yang diperoleh maksimal tanpa menganggu kelestarian ikan Lencam. Lebih lanjut lagi dilakukan penelitian mengenai aspek biologi, oseanografi dan tingkah laku ikan Lencam di perairan Pulau Obi Kabupaten Halmahera Selatan.

\section{DAFTAR PUSTAKA}

Ayodhyoa, A. U., 1981. Metode Penangkapan_Ikan. Penerbit Yayasan Dewi Sri. Bogor.

Dahuri, 2001. Pengolahan Sumberdaya Wilayah Pesisir dan Lautan Secara Terpadu. Penerbit PT. Pradnya Paramita. Jakarta.

Dinas Kelautan dan Perikanan, 2018. Data Potensi Perikanan Kabupaten Obi. Maluku Utara.

Dinas Perikanan, 1993. Evaluasi Pembangunan Sub Perikanan Selama Pelita V dan Kesiapan Untuk Memasuki PJPT II Khususnya Pelita VI. Dinas Perikanan. Maluku.

Dirjen Perikanan, 1979. Sumberdaya Perikanan Laut Jenis-Jenis Ikan Ekonomis Penting. Departemen Pertanian. Jakarta.

Hariani, 1992. Study Tentang Penangkapan Ikan Baronang (Siganus spp) Dengan Alat Tangkap Jaring Insang Lingkar Di Perairan Pantai Mamuju. Skripsi Jurusan Pemanfaatan Sumberdaya Perikanan. Fakultas Perikanan UMI. Ujung Pandang. 
Iqbal. H.M, 1999. Pokok-Pokok Materi Statestik I. Penerbit Bumi Aksara. Jakarta.

Murtini.S, 1998. Potensi dan Beberapa Parameter Dinamika Populasi Ikan Lencam (Lethrinus lentjan) Di Sekitar Perairan Kecamatan Bonto Manete Kabupaten Selayar. Skripsi Jurusan Ilmu Kelautan. Fakultas Kelautan dan Perikanan. Universitas Hasannudin. Ujung Pandang.

Nirmalawati.A. 1996. Potensi Dinamika Populasi Dan Tingkat Eksploitasi Ikan Lencam Matahari (Lethrinus lentjan) Di Sekitar Perairan Pantai Desa Madello Kabupaten Barru. Skripsi Jurusan Pemanfaatan Sumberdaya Perikanan. Fakultas Perikanan UMI. Ujung Pandang.

Firnawati, 1997. Study Perbandingan Jumlah dan Komposisi Jenis Hasil Tangkapan Gilnet Permukaan Pertengahan dan Dasar di Perairan Kendari. Skripsi Jurusan Pemanfaatan Sumberdaya Perikanan. Fakultas Perikanan UMI. Ujung Pandang.

F A 0, 1995. Menangkap Ikan Dengan Jaring Letak Dasar. Penerbit Bhatara. Jakarta.

Fridman, A.L., 1986. Perhitungan Dalam merancang Alat Penangkapan Ikan. Koperasi Serba Usaha Perikanan Balai Pengembangan Penangkapan Ikan. Semarang.

Subani dan Barus, 1988. Alat Penangkapan Ikan dan Udang Laut di Indonesia. Balai Penelitian Laut. Departemen Pertania. Jakarta.

Sadhori, N.S., 1984. Teknik Penangkapan Ikan. Penerbit Angkasa. Bandung.

Sparre dan Venema, 1999. Introduksi Pengkajian Stok Ikan Tropis. Pusat Penelitian dan Pengembangan Perikanan. Badan Penelitian dan Pengembangan Pertanian. Jakarta.

Saanin. H. 1984. Taksonomi Dan Kunci Identifikasi Jilid I Dan II. Penerbit Bina Cipta. Bogor. 